\title{
MAHDIISME DALAM HADIS-HADIS MAHDAWIYAH
}

\author{
Muhammad Rikza Muqtada \\ Institut Agama Islam Negeri Salatiga - Indonesia \\ e-mail: mrmcandi@gmail.com
}

\begin{abstract}
This paper discusses the origins of Mahdiism (al-Mahdi al-Muntazar) that are constructed using the mahdawiyyah hadith with the status of ahad (single transmitter) and da'if (weak). Nevertheless, this belief (Mahdiism) has deep roots in the theological reason of Muslims. By the historical approach, the finding shows that Mahdiism has roots in millenarianism (belief of the saviors' presence) that had existed in pre-Islamic traditions, such as Jewish and Christian. The elementary form of Islamic millenarianism is the concept of prophethood, but when the prophethood concept was deemed finished, it continued into the concept of Mahdiism. The first emergence of Mahdiism is in line with the emergence of mahdawiyyah hadith. The emergence context of the mahdawiyyah hadìth revolves around the power transition from the Umayyad dynasty to the Abbasid dynasty, which always involved Shiite followers as the political victims. The contact between Shiites with the Jewish former and Christian former during the conflict at that time influenced the style of Shiite theology, like as millenarianism. The Shi'ites propagate the presence of al-Mahdi, as the savior from descendants of the prophet (Ahl al-Bait) described through the mahdawiyyah hadiths. Among the narrators of mahdawiyyah hadith are Jewish former (Ka'ab al-Ahbar) and Christians former (Wahb b. Munabbih). They were the pioneers who incorporated the millenarianism into the Mahdiism.
\end{abstract}

\begin{abstract}
Abstrak: Tulisan ini membahas tentang asal-usul Mahdiisme (tentang al-Mahdi al-Muntazar) yang dikonstruk menggunakan hadis-hadis mahdawiyyah yang berstatus aḥad (tunggal) dan da'îf (lemah). Meskipun demikian, keyakinan tentang Imam Mahdi ini telah mengakar kuat dalam nalar teologis umat Islam. Dengan pendekatan sejarah pemikiran, temuan menunjukkan bahwa Mahdiisme memiliki akar-akar dari millenarianisme (paham tentang kehadiran juru selamat) yang ada dalam agama-agama pra-Islam, Yahudi dan Nasrani. Bentuk awal millenarianisme Islam adalah konsep kenabian, namun ketika konsep tersebut dinyatakan selesai, maka berlanjut ke dalam konsep Mahdiisme. Kemunculan awal Mahdiisme sejalan dengan kemunculan hadis-hadis mahdawiyyah. Konteks kemunculan dan perkembangan hadis-hadis mahdawiyyah adalah seputar masa transisi kekuasaan dari Dinasti 'Umayyah kepada Dinasti 'Abbasiyyah, di mana selalu melibatkan pengikut-pengikut Syi'ah sebagai korban politik. Persinggungan kaum Syi'ah dengan mantan agamawan Yahudi dan Nasrani pada konflik saat itu. memberikan pengaruh terhadap corak teologi Syi'ah, millenarian. Kaum Syi'ah mempropagandakan kehadiran al-Mahdi sebagai sosok penyelamat dari keturunan Ahl al-Bait yang digambarkan melalui hadis-hadis mahdawiyyah. Di antara para perawi hadis mahdawiyyah adalah mantan agamawan Yahudi (Ka'ab al-Ahbar) dan agamawan Nasrani (Wahab ibn
\end{abstract}


Munabbih). Merekalah yang memasukkan gagasan millenarianisme ke dalam mahdiisme.

Keywords: mahdiism, Shi' ite followers; mahdawiyyah hadith; Ahl al-Bait

\section{A. Pendahuluan}

Konsepsi dasar teologi Islam adalah al-Qur'an, sedangkan gambaran detailnya secara normatif dijelaskan melalui hadis. Sejak masa awal Islam, bersama al-Qur'an, hadis berperan penting dalam membangun teologi, pengetahuan, dan dinamika kebudayaan dalam Islam. ${ }^{1}$ Hadis menjadi kunci dalam setiap pengkajian terhadap kesejarahan Islam. Maka kajian tentang teologi Islam, hendaklah dimulai dari statemen al-Qur'an. Kecocokan antara statemen al-Qur'an dengan hadis-hadis yang berkaitan cukup membuktikan keotentikan sebuah keyakinan. Sebaliknya, jika terjadi perbedaan antara keduanya tentu hadislah yang menjadi sumber masalah. ${ }^{2}$

Terdapat sebuah teologi dalam Islam yang pengaruhnya begitu kuat bagi mayoritas pemeluknya, tetapi al-Qur'an sama sekali tidak memberikan landasan bagi teologi itu, yaitu tentang al-Mahdi atau mahdiisme. Informasi tentang alMahdi hanya bisa ditemukan dalam hadis-hadis mahdawiyyah. ${ }^{3}$ Selain problem kecocokan dengan al-Qur'an, mahdiisme memiliki problem internal pada hadishadisnya. Paham ini tidak disebutkan dalam Șaḥiḥain (Șaḥịh al-Bukhārī dan Șậh Muslim) sebagai kitab hadis yang paling otoritatif.4 Hadis ini dinilai 'bermasalah' oleh sebagian kritikus hadis. ${ }^{5}$ Ibn Khaldūn (w. 1406 M) dalam al-

1David Cook, "Hadīth', Authority and the End of the World: Traditions in Modern Muslim Apocalyptic Literature," Oriente Moderno 21, no. 82 (2002): 31-53, https://www.jstor.org/ stable/25817811.

${ }^{2}$ Kerangka ini berawal dari penelitian David S. Powers yang menguji kesetiaan hukum Islam (hukum waris) terhadap legislasi al-Qur'an. Powers mencoba membuktikan tesis Schacht yang menyatakan bahwa hadis baru terbentuk abad ke-2 Hijrah. Melalui analisa historis, Powers menyimpulkan sekaligus membantah kesimpulan Schacht dengan menunjukkan bahwa terbentuknya hadis pada masa awal Islam merupakan bentuk kesinambungan dari tradisi-tradisi pra-Islam yang kemudian mempengaruhi otoritas-otoritas Muslim dalam menafsirkan ayat-ayat al-Qur'an berdasarkan riwayat-riwayat hadis. David S Powers, Studies in Qur'an and Hadith: The Formation of the Islamic Law of Inheritance (London: University of California Press, 1986), 1-10.

${ }^{3}$ Hadis-hadis yang menyebutkan tentang kehadiran al-Mahdi beserta ciri-cirinya.

${ }^{4}$ A. R. I. Doi, “The Yoruba Mahdi," Journal of Religion in Africa 4, no. 2 (1971): 119-36, https://doi.org/10.2307/1594738.

${ }^{5}$ Hadis-hadis ini dinilai lemah dan palsu oleh beberapa tokoh, seperti Ibn Khaldūn, Ahmad Amīn, dan al-Ẓahabī. Hadis-hadis tersebut akan dibahas di belakang. Shamsuddīn Muhammad ibn Ahmad ibn Uthmān al-Ẓahabī, Talkhīs Kitāb al-'Ilal al-Mutanāhiyah li Ibn al-Jauzī, ed. Abū Tamīm Yasīr ibn Ibrāhīm (Riyāz: Shirkah al-Riyāz, 1998), 311-21. 
Muqaddimah-nya menyebut mahdiisme dalam Islam dikonstruk hanya melalui 25 hadis mahdawiyyah, dan masing-masing hadisnya memiliki problem otentisitas. Di antara perawi-perawi hadisnya terindikasi tashayyu' (mengandung unsur-unsur Syi'ah). ${ }^{6}$ Lebih lanjut Ibn Khaldūn menyebutkan:

It has been accepted by all Muslims in every epoch, that at the end of time a man from the family [of the Prophet] will without fail make his appearance, one who will strengthen Islam and make justice triumph. Muslims will follow him, and he will gain domination over the Muslim realm. He will be called the Mahdi. Following him, the Antichrist will appear, together with the subsequent signs of the Day of Judgment. After the Mahdi, [the Prophet] Isa [Jesus] will descend and kill the Antichrist. Or, Isa will descend together with the Mahdi and help him kill the Antichrist. Such statements have been found in the hadiths that religious leaders have published. ${ }^{7}$

Ahmad Amīn menyebutkan paham ini mulai menguat sejak masa transisi kekuasaan dari Dinasti ‘Umayyah kepada Dinasti 'Abbasiyyah. Dalam kontestasi politik saat itu selalu melibatkan loyalis Ahl al-Bait sebagai pihak ketiga yang tertindas dan kalah. Sebab itu, pemuka kelompok oposan ini sengaja menghadirkan hadis-hadis mahdawiyyah yang berisi harapan-harapan utopis yang mengatakan bahwa kemenangan ada di bawah pimpinan keturunan mereka, yang mereka sebut sebagai al-Mahdi. ${ }^{8}$

Hadis-hadis mahdawiyyah juga ditemukan dalam kitab-kitab hadis induk Syi'ah, salah satu kelompok besar Islam yang memiliki intensi pengkajian hadis dengan tradisi yang berbeda. ${ }^{9}$ Di dalam kitab hadis induk Syi'ah, al-Käfi al-Kulaini, jelas terdapat hadis mahdawiyyah, namun yang diceritakan justru sosok fiktif

${ }^{6}$ Abū Zaid 'Abd al-Rahmān ibn Muhammad Ibn Khaldūn, "Bāb fí Amri al-Fātimī wa Mā Yazhabu ilaihi al-Nās fì Sha'nihi," dalam al-Muqaddimah li Ibn Khaldūn, ed. Abdullah Muhammad Darwis, vol. 1 (Damsyiq: Dār Yu'rab, 2004), 514-44; Laurent Murawiec, The Mind of Jihad, 1 ed. (Cambridge; New York: Cambridge University Press, 2008), 109.

7Ibn Khaldūn, The Muqaddimah: An Introduction to History, ed. oleh N. J. Dawood, trans. Franz Rosenthal (Princeton: Princeton University Press, 2015), 156; Murawiec, The Mind of Jihad, 109; David Cook, Contemporary Muslim Apocalyptic Literature, 1 ed. (Syracuse, NY: Syracuse University Press, 2008), 9.

${ }^{8}$ Ahmad Amīn, al-Mahdi wa al-Mahdawiyyah (Cairo: Muassasah Handawi li al-Ta'lìm wa alThaqafah, 2012), 5, 11, 48.

${ }^{9}$ Millenarianisme merupakan istilah untuk menyebutkan suatu paham atau ideologi yang meyakini akan datangnya Juru Selamat (Messiah) pada umat yang kondisi sosialnya tertindas akibat merajalelanya kezaliman rezim penguasa. Istilah ini memiliki kesamaan istilah dengan millenialisme, messianik, mahdiisme, atau al-mahdiyyah. 
yang diyakini sebagai al-Mahdi, yakni putra dari Imām Ḥasan al-Askarī (Imam Syi'ah ke-11), padahal faktanya Imam Ḥasan al-Askarī tidak memiliki putra. ${ }^{10}$

Kajian tentang asal-usul teologi tentu berangkat dari pemikiran-pemikiran keagamaan klasik yang bisa dikaji melalui teks-teks agama secara cross references. Mengkaji tentang mahdiisme meniscayakan untuk mengkaji pemikiranpemikiran millenarian yang ada pada Yahudi dan Nasrani melalui teks-teks keagamaannya. Selanjutnya adalah mengkaji historisitas hadis-hadis mahdawiyyah yang menjadi dasar mahdiisme, mulai dari kemunculan, proses transmisi dan proses divusinya di kalangan umat Islam.

\section{B. Reposisi Hadis dalam Nalar Teologis}

Kajian tentang asal-usul mahdiisme memang berangkat dari teks hadis yang menurut al-Zahabi dan beberapa kritikus lainnya tergolong 'bermasalah'. Sebab itu perlu keberanian untuk menyikapi hadis-hadis tersebut secara kritis. Hadis tidak lagi ditempatkan pada wilayah yang sakral, hanya karena ia sebagai sumber teologi. Kajian terhadap kesejarahan teologi atau pemikiran masa lalu, dalam praktek sejarawan pemikiran dapat dipelajari dari teks maupun arsip. ${ }^{11}$ Dalam tulisannya, Kuntowijoyo memberikan catatan tebal pada 'pada mulanya adalah teks'.12 jika dikaitkan dengan tugas sejarah pemikiran, maka sejarah pemikiran selalu berkaitan dengan teks, konteks sejarah, dan hubungan antara teks dan masyarakatnya. ${ }^{13}$ Hadis sebagai fenomena teks hendaknya diposisikan sebagai data sejarah. Pengkajian terhadap hadis tidak lagi cukup dengan mengetahui kevalidan, keotentikan serta pemahaman hadis, tetapi ia harus disinergikan dengan data-data sejarah lain, sekalipun pada persoalan teologis.

Penolakan terhadap hadis hanya karena tidak otentik, bagi Fazlur Rahman, merupakan pengabaian atau kebutaan terhadap proses evolusi hadis yang keberadaannya tidak bisa lepas dari historisitasnya. Proses evolusi sunnah (tradisi yang hidup) menjadi hadis (verbalisasi tradisi), dalam pandangan Rahman, memiliki hubungan kontinuitas sejarah yang unik di antara agama-

\footnotetext{
${ }^{10}$ Muslih Fathoni, Paham Mahdi Syi'ah dan Ahmadiyah dalam Perspektif (Jakarta: Raja Grafindo Persada, 1994), 4. 2014), 56.

${ }^{11}$ Nyong Eka Teguh Iman Santosa, Sejarah Intelektual: Sebuah Pengantar (Sidoarjo: UruAnna,

${ }^{12}$ Kuntowijoyo, "Sejarah Pemikiran,” dalam Metodologi Sejarah (Yogyakarta: Tiara Wacana, 2003), 201.

${ }^{13}$ Kuntowijoyo, 193.
} 
agama besar dunia. Nabi Muhammad bukan membentuk agama melainkan mengembangkan suatu tradisi masyarakat yang sudah ada sebelumnya. ${ }^{14}$ Karena itu terdapat kontinuitas tradisi dari masa sebelum Muhammad kemudian berlanjut hingga masa sesudahnya, dan semuanya terekam dalam teks hadis.

Konsep hadis menjadi data sejarah membawa kesempatan bagi pengkaji untuk menggali apa yang sebenarnya terjadi pada masa Nabi Muhammad hidup (what really happen in the past?). Karena itu, kajian hadis akan selalu terkait dengan sejarah kehidupan Nabi Muhammad dan sahabat-sahabatnya serta reliabilitas (keterpercayaan) setiap generasi ulama serta kemampuannya dalam mentransmisikan berita dari sahabat awal hingga saat ini. Apabila proses transmisi hadis adalah tunggal tentu tidak dijumpai adanya hadis-hadis kontradiktif yang menyebabkan heterogenitas pandangan, namun fakta tidak demikian. Konsekuensinya apakah hadis itu benar dari Nabi Muhammad atau justru refleksi pendapat ulama? Meskipun keberadaan hadis diragukan berasal dari Nabi Muhammad, setidaknya hadis bisa diterima sebagai laporan-laporan yang menggambarkan masa-masa awal Islam dan kemudian dijadikan rujukan historis dalam menggali bentuk asli teologi Islam. Sebab itu bukan berarti harus membuang hadis-hadis 'bermasalah' tetapi tetap menjadikannya sebagai aset ilmiah.

\section{Dari Millenarianisme ke Mahdiisme}

Mahdiisme merupakan paham yang menunggu kehadiran al-Mahdi sebagai sosok penyelamat di hari akhir nanti. Sebab itu, pengkajian tentang asal-usulnya harus dimulai dari gagasan besar tentang kehadiran juru selamaat, yakni millenarianisme. Millenarianisme merupakan ide apokalipsis yang sering ditemukan pada kelompok-kelompok tertindas yang tradisi dan kulturnya terganggu oleh pengaruh asing. Gangguan-ganguan itu bisa berasal dari kelompok lain atau penguasa otoriter. Apabila ganguan itu sudah semakin parah sehingga menimbulkan tekanan, kerugian dan kesulitan bagi kelompok tertindas (deprivasi) maka muncullah gerakan millenarian sebagai bentuk perlawanan kultural untuk menghilangkan penindasan akibat perubahan-perubahan sosial yang merugikan dan membahayakan status kelompok yang tertindas. ${ }^{15}$

\footnotetext{
${ }^{14}$ Fazlur Rahman, Islam (Chicago \& London: University of Chicago Press, 1977), 101-4.

${ }^{15}$ Sylvia L. Thrupp, "Impian-Impian Millenial di dalam Aksi: Laporan Mengenai Diskusi Konperensi," dalam Gebrakan Kaum Mahdi: Studi tentang Gerakan-Gerakan Keagamaan
} 
Objek kajian milleniarisme selalu terfokus pada wilayah-wilayah jajahan. Kaum millenarian sering menampilkan gerakan revolusioner di tengah-tengah pergolakan revolusi. ${ }^{16}$ Gerakan semacam ini merupakan bentuk protes sosial akibat dari pergolakan politik yang berambisi untuk merebut kekuasaan dalam persaingan politis, bisnis, tradisi, sosial dan sebagainya. Masing-masing kelompok berusaha untuk menunjukkan eksistensinya. ${ }^{17}$ Oleh karena itu millenarianisme menjadi modus gerakan masyarakat 'primitif yang tertindas serta mengalami perubahan drastis dalam struktur sosialnya untuk melakukan protes sosial terhadap rezim penguasa sekaligus merebut kejayaannya kembali.

Michael J. Brisbois mendefinisikan millenarianisme sebagai berikut:

Perhaps the most direct way to define millenarianism is to describe it simply as a socio-cultural response to alienation or disenfranchisement that combines an idealized past with a desire for imminent redemption in order to create a hopeful, utopian society in the future. Such a definition is serviceable and encapsulates the most important and most salient developments in current research, but it lacks a historical or contextual grounding. Conventionally, millenarianism is most often associated with the religions of Abraham and with Christianity specifically. ${ }^{18}$

Statemen Brisbois di atas sekaligus menunjukkan bahwa millenarianisme bukan paham baru, tetapi sudah berlangsung lama dalam tradisi-tradisi klasik sejarah peradaban manusia, terutama agama-agama semitis. Millenarianisme pun telah menjadi ideologi lintas sejarah (transhistoris) dan lintas negara (transnasional). ${ }^{19}$

Dalam Islam, gagasan millenarianisme sangat dipengaruhi oleh mantan ahlu kitab, seperti Ka'ab al-Aḥbar (Yahudi Yaman), Hudaifah ibn al-Yaman, al-

Revolusioner, ed. Sylvia L. Thrupp, Tohiruddin Lubis, trans. Anas Muhyiddin (Bandung. Pustaka, 1984), 5.

${ }^{16}$ Norman Chon, "Milleniarisme Zaman Pertengahan: Hubungannya dengan Studi Komparatif Gerakan-gerakan Millenarian," dalam Gebrakan Kaum Mahdi: Studi tentang Gerakan-Gerakan Keagamaan Revolusioner, ed. Sylvia L. Thrupp, trans. oleh Anas Muhyiddin (Bandung: Pustaka, 1984), 49.

${ }^{17}$ Maya Yazigi, “William F. Tucker, Mahdis and Millenarians: Shi ite Extremists in Early Muslim Iraq (Cambridge: Cambridge University Press, 2008). Pp. 204. $\$ 96.00$ cloth, $\$ 30.00$ paper, $\$ 68.00$ ebook.," International Journal of Middle East Studies 43, no. 3 (2011): 573-75, https://doi.org/ 10.1017/S0020743811000808.

18Michael J. Brisbois, "Millenarian Moderns: A Study of Utopian Desire” (University of Calgary, 2013), 12, https://doi.org/10.11575/PRISM/26918.

${ }^{19}$ Brisbois, 13. 
Walid ibn Muslim, dan Wahb ibn Munabbih (Nasrani Arab Selatan), yang memasukkan keterangan-keterangan isrä ̂̄iliyyat ke dalam penafsiran-penafsiran alQur'an, hadis-hadis dan sumber-sumber agama Islam lainnya. ${ }^{20}$ Dari merekalah elemen-elemen ajaran Yahudi maupun Nasrani masuk ke dalam ajaran Islam. Karena itu perlu untuk mengkomparasikan literatur-literatur millenarianisme Islam dengan literatur-literatur millenarianisme yang terdapat dalam tradisi Yahudi dan tradisi Nasrani. Di samping itu, melalui dating (penanggalan) terhadap literatur-literatur tersebut setidaknya dapat mengetahui aspek kesejarahan dalam penyebaran ide millenarian.

Ketiga agama itu memang menerima millenarianisme, namun mereka mengekspresikannya secara berbeda meskipun substansinya hampir memiliki kesamaan. Sebab itulah terdapat dua kesulitan dalam mengidentifikasi elemenelemen apokalipsis millenarianisme yang dimiliki tradisi Yahudi dan Nasrani yang masuk dalam tradisi Islam; 1) sulit untuk menentukan sumber apokalipsis karena dalam tradisi Islam secara umum tidak menyebutkannya, dan 2) sulit untuk memisahkan refleksi apokalipsis Yahudi dari apokalipsis Nasrani karena pengaruh kuat pemikiran apokalipsis Yahudi ditulis oleh orang-orang Nasrani. ${ }^{21}$ Meski demikian, kemungkinan transmisi millenarianisme tetap dapat diidentifikasi dengan term-term yang jelas, yakni Messiah.

Yahudi merupakan agama yang sangat kental dengan millenarianisme. Moses (w. 1407 SM), David (1040-970 SM), Salomo (971-931 SM) dan Elijah (910-852 SM) disebut sebagai Messiah oleh tradisi Israel. Mereka adalah penyelamat dari rezim-rezim yang pernah menindas umat Yahudi. Nubuwat tersebut disebutkan dalam kitab Daniel bab III, Raja-raja 11: 12, Ezekiel 37: 2628, Isaiah 43: 5-6, Eksodus: 32, Eksodus 17: 8-6 dan Joshua 1: 1-9. Pengalaman pahit selama ribuan tahun membuat alam pikiran umat Yahudi menjadi tangguh dan khas, sehingga saat ini konsep-konsep mereka diterima oleh banyak kalangan di dunia. Garaudy menyatakan, millenarianisme merupakan sumbangan besar yang diberikan oleh Yudaisme kepada seluruh peradaban dunia. ${ }^{22}$

20 Ofer Livne-Kafri, “Some Notes on the Muslim Apocalyptic Tradition,” Quaderni di Studi Arabi 17 (1999): 79-80; 85, https://doi.org/10.2307/25802868; Zeki Saritoprak, "The Mahdī Tradition in Islam: A Social-Cognitive Approach," Islamic Studies 41, no. 4 (2002): 664, https://doi.org/ $10.2307 / 20837234$.

${ }^{21}$ Livne-Kafri, "Some Notes on the Muslim Apocalyptic Tradition," 77.

${ }^{22}$ Roger Garaudy, Zionis Sebuah Gerakan Keagamaan dan Politik, terj. Moelia Radja Siregar (Jakarta: Gema Press Insani, 1995), 38.

JURNAL THEOLOGIA — Volume 30, No. 2, December 2019 
Pemikiran ini masuk ke dalam Islam melalui peran mantan agamawan Yahudi Ka'ab al-Ahbar (w. 34 H/655 M) ${ }^{23}$ dan 'Abdullāh ibn Saba' (w. 49 H/670 M). Keduanya terlibat dalam periwayatan hadis Mahdawiyah.

Tradisi Nasrani mengenalkan Yesus sebagai Kristus atau Messiah. Kemessiahan Yesus disebutkan dalam Kitab Wahyu dengan hadirnya Yesus untuk kedua kalinya dengan tujuan menegakkan kerajaan messianik di atas bumi dan ia akan memegang tampuk kepemimpinan di dalam kerajaan ini selama seribu tahun sebelum hari kiamat tiba, serta melawan pihak-pihak yang menyesatkan mereka seperti Gog dan Magog dan Iblis. ${ }^{24}$ Gagasan Nasrani ini masuk ke dalam Islam melalui Wahb ibn Munabbih (w. 117 H/738 M), mantan agamawan Nasrani, khususnya keterkaitan antara al-Mahdi dan Isa ibn Maryam..$^{25}$

Awalnya millenarianisme dihadirkan sebagai gerakan sosial-politis, namun dalam perkembangannya beralih menjadi gerakan teologis-eskatologi. ${ }^{26}$ Revolusi millenarian selalu dipimpin oleh seorang 'Nabi'. Selama bertahun-tahun gerakan millenarian selalu di bawah bayang-bayang wahyu, dan kemudian menyeru kepada orang-orang miskin/tertindas sebagai calon pengikut-pengikutnya di tengah-tengah pergolakan sosial. ${ }^{27}$ Dalam sejarah kenabian agama semitis, ketokohan Musa sebagai Messiah bagi kaum Israel dalam menumbangkan rezim Fir'aun (Pharao), ${ }^{28}$ Dawud dan Sulaiman dalam menyelamatkan kaum Israel dari rezim Raja Jalut (Goliath), ${ }^{29}$ Isa dalam menyelamatkan kaum Israel dari imperial

${ }^{23}$ Ka'ab al-Ahbar adalah mantan agamawan Yahudi Yaman yang bernama lengkap Ka'ab ibn Māti al-Himyārī. la yang ditengarai sebagai orang yang menerjemahkan kitab Daniel ke dalam bahasa Arab pasca penaklukan Islam ke Persia. Secara langsung atau tidak ia telah memasukkan elemen-elemen apokalipsis ke dalam literatur-literatur Islam, termasuk hadis. Abū 'Abdullāh Nu'aim ibn Hammad ibn Mu'awiyah ibn al-Harith Al-Khuzai, Kitāb al-Fitan, ed. oleh Samīr Amīn Al-Zuhairi, vol. 2 (Cairo: Maktabah al-Tawhīd, 1412), 696-99; 'Abd al-Fatah Tawakkal, "Ka'b al-Ahbār and the Isräiliyyāt in the Tafsīr Literature" (Montreal: McGill University, 2007), 1-2.

${ }^{24}$ Wahyu 20: 1-10.

${ }^{25}$ Abū Ja'far Muhammad ibn 'Alī ibn al-Husain al-Qummi, "Naș Allāh swt. 'alā al-Qā’im as.," dalam Kamāl al-Dīn wa Ittmām al-Ni'mah, ed. Ḥusain Al-A'lāmi, vol. 23 (Beirut: Muassasah al-A'lāmī li al-Mațbūāt, 1991), 239.

${ }^{26}$ Fathoni, Paham Mahdi Syi'ah dan Ahmadiyah dalam Perspektif, 3.

${ }^{27}$ Chon, "Milleniarisme Zaman Pertengahan: Hubungannya dengan Studi Komparatif Gerakangerakan Millenarian," 51.

${ }^{28}$ Franz Delitzsch, Messianic Prophecies in Historical Succession (New York: Charles Scribner's Sons, 1891), 59-73.

${ }^{29}$ Delitzsch, 80-101; Morteza Yousofi, "Reading Robinson Crusoe from the lens of Islamic Utopianism," International Journal of Applied Linguistics \& English Literature 3, no. 2 (2014): 187-93, https://doi.org/10.7575/aiac.ijalel.v.3n.2p.187. 
Romawi, dan ketokohan Muhammad dalam melawan tribalisme dan perbudakan bangsa Arab pra-Islam. ${ }^{30}$ Jelas bahwa agama-agama besar dunia yang mengakar pada keyakinan Abrahamik sangat kental dengan millenarianisme.

Christianity is perhaps the most intensely millenarian of major faiths, and the very terminology of the millennium, especially the terms apocalypse and Armageddon, are taken from the Book of Revelation (Apokalypsis in the original Greek). The millenarianism of Judaeo-Christianity continues into Islam, creating a new series of eschatological beliefs about the future, so that each religious tradition that traces its origin to Abraham is millenarian. ${ }^{31}$

Setiap agama bisa dikatakan millenarian, dalam arti memiliki unsur pemimpin kharismatik (charismatic leader), teks teologis (wahyu) dan gerakan revivalis yang mengajak pada keselamatan dan kejayaan. Meskipun telah ditegaskan dalam QS. al-Aḩzāb [33]: 40 dan 43 bahwa Muhammad adalah juru selamat sekaligus Nabi terakhir, ternyata dalam beberapa nalar sekte-sekte Islam tetap tersisa ide-ide millenarian di hari akhir kelak, yakni kehadiran Isa dan al-Mahdi.32

Konsep kenabian merupakan bentuk awal millenarianisme dalam Islam, namun pasca Muhammad (w. $11 \mathrm{H} / 632 \mathrm{M}$ ) dinyatakan sebagai khatam alanbiy $\bar{a}^{33}$ maka terjadi kekosongan charismatic leader di internal umat Islam. Untuk mengisi posisi itu maka dihadirkan konsep tentang al-Imām, dan sosok yang menyandang gelar itu disepakati dan diperkenalkan sebagai al-Mahdi. Narasi hadis-hadis Mahdawiyah mengilustrasikannya sebagai keturunan Muhammad. Hal ini memberi arti bahwa al-Mahdi masih berada dalam barisan 'agama resmi' yang didirikan oleh Muhammad (w. 11 H/632 M) ${ }^{34}$ sekaligus sosok yang sah dalam mewarisi misi kenabiannya, yang juga berarti kepemimpinan atas umat Islam.

Keyakinan terhadap al-Mahdi yang bergitu kuat menyebabkan paham millenarian dalam Islam ini dikenal dengan "mahdiisme". Pembahasan tentang

\footnotetext{
30Ronald Albert Graff dan Lambert T. Dolphin, Connecting the Dots: A Handbook of Bible Prophecy (Longwood: Xulon Press, 2010), 24.

${ }^{31}$ Brisbois, "Millenarian Moderns: A Study of Utopian Desire," 13.

${ }^{32}$ Saleh Asyabibi Nahdi, Imam Mahdi Atau Ratu Adil? (Jakarta: Arista Brahmatyasa, 1992), 1.

${ }^{33} \mathrm{Al}$ Makin, Representing the Enemy: Musaylima in Muslim Literature (Frankfurt: Peter Lang, 2010), 82-87; Abraham Silo Wilar, "Muhammad as Seal of the Prophets: The Question of Ideology in Majority Muslim, Ahmadiya Muslim, and Western Readings of Seal," Penamas 27, no. 2 (2014): 137148, http://blajakarta.kemenag.go.id/journal/index.php/penamas/article/view/75. 10.

${ }^{34} \mathrm{Al}$ Makin, Nabi-Nabi Nusantara: Kisah Lia Eden dan Lainnya (Yogyakarta: SUKA-Press, 2017),
} 
mahdiisme sangat banyak ditemukan dalam teologi kelompok Syi'ah. Setidaknya ada kesamaan unsur dalam konsep mahdiisme dalam Syi'ah dan milleneraianisme dalam Nasrani. Mahdiisme dalam Syi'ah mengharapkan kembalinya Imam-imam mereka yang telah menjadi korban pembantaian oleh musuhmusuh mereka, ${ }^{35}$ sedangkan millenarianisme dalam Nasrani mengharapkan kembalinya Yesus yang pernah menjadi korban salib oleh lawan politiknya. ${ }^{36}$ Semakin jelas adanya transformasi millenarianisme dari Nasrani ke dalam Islam.

\section{Kemunculan Mahdiisme dalam Kontestasi Politik Islam Awal}

Periode eskatologi Islam berawal dari masa pasca meninggalnya Nabi Muhammad. ${ }^{37}$ Masa-masa itulah yang menjadi titik tolak dalam setiap pembahasan sejarah teologi Islam, pada masa-masa itu pula hadis mulai disandarkan pada otoritas-otoritas Muslim. Maka kajian terkait permulaan mahdiisme dan hubunganya dengan kemunculan hadis-hadis mahdawiyyah berawal dari masamasa pasca meninggalnya Nabi Muḥammad.

Peristiwa inagurasi Abū Bakar sebagai Amìr al-Mu'minīn (12 H/634 M) tidak diketahui oleh pihak 'Alī ibn Abū Țālib, sehingga mengundang spekulasi tentang siapa tokoh-tokoh dari kalangan sahabat yang lebih berhak meneruskan leadership Muhammad. Terjadilah kontestasi politik yang melibatkan sahabatsahabat dari kelompok Muhājirin (yang berhijrah) dan kelompok Anșār (yang memberi suaka bagi kaum Muhājirīn). Di pihak lain, golongan Bani Hasyim muncul serta merasa berhak atas jabatan kepemimpinan itu, sehingga sebagian dari mereka ada yang ingin membaiat 'Alī ibn Abū Țālib sebagai khalifah, meskipun ditolak oleh 'Alī. Akibatnya para pendukung 'Alī ibn Abū Ṭālib banyak yang menunda-nunda untuk membai'at Abū Bakar sebagi pimpinan. ${ }^{38}$ Setelah kepemimpinan Abū Bakar usai, jabatan Amīr al-Mu'minīn justru jatuh ke tangan 'Umar ibn Khațtāb. Hal ini menambah kekecewaan bagi pendukung 'Alī, sehingga mendorong mereka untuk mengisukan keberhakan Ahl al-Bait sebagai amir. ${ }^{39}$

\footnotetext{
${ }^{35}$ Terbunuhnya Imam 'Alī ibn Abi Thalib, terbunuhnya Imam Husain ibn 'Alī, ditikungnya Imam Muhammad ibn al-Hanafiyah dan hilangnya Imam ke-12 mereka.

${ }^{36}$ Riffat Hassan, "Messianism and Islam," Journal of Ecumenical Studies 22, no. 2 (1985): 272, http://soerenkern.com/pdfs/ islam/MessianismAndIslamHassan.pdf.

37Livne-Kafri, "Some Notes on the Muslim Apocalyptic Tradition," 74.

${ }^{38}$ Fathoni, Paham Mahdi Syi'ah dan Ahmadiyah dalam Perspektif, 18.

${ }^{39}$ Yehoiakin Ben Yaocof, Concepts of Messiah: A Study of the Messianic Concepts of Islam, Judaism, Messianic Judaism, Christianity (Bloomongton, Indianapolis: WestBow Press, 2012), 8.
} 
Usaha untuk mengukuhkan 'Alī ibn Abū Țālib sebagai amīr al-mu'minīn selalu tertunda hingga 'Uthmān ibn 'Affān (55 H/644 M) mati terbunuh. Selama masa kepemimpinan 'Uthmān ibn 'Affān justru menjadi kesempatan emas bagi Bani 'Umayyah untuk menggalang kekuatan politik meritokrasi. 'Uthmān dinilai menganakemaskan orang-orang dari klan 'Umayyah. Banyak dari mereka yang diangkat sebagai pejabat struktural dalam birokrasi 'Uthmān ibn 'Affān. Perselisihan antara kubu 'Umayyah dan loyalis ahl al-bait bisa dikatakan sebagai buntut konflik masa lalu. Apabila ditarik ke belakang, sejarah mencatat adanya persaingan antara Abū Sufyan, selaku nenek moyang Bani 'Umayyah, dengan Nabi Saw. selama kurang lebih 20 tahun dalam hal penguasaan kota Makkah. Kondisi sosial yang tidak menguntungkan pihak 'Alī ibn Abū Ṭalib justru meningkatkan tensi politik para pengikut 'Alī untuk melakukan tindakan revolutif dengan mengangkat isu keberhakan Ahl al-Bait sebagai $a m i \bar{r}$.

Bahkan setelah 'Alī ibn Abū Țālib terangkat menjadi $a m i ̄ r$, segala bentuk serangan dan terror pun dilancarkan oleh kekuatan-kekuatan Bani 'Umayyah. Kedaulatan kepemimpinan 'Alī senantiasa digerogoti. Kekalahan-kekalahan pihak 'Alī dalam diplomasi politik dalam peristiwa daumat al-jandal dan tahkìm yang berujung pada terbunuhnya 'Alī ibn Abū Ṭālib (41 H/ 661 M) oleh seorang Khawarij, Ibnu Muljam, menjadi pukulan berat bagi pendukung Ahl al-Bait. Kondisi semakin diperparah dengan terbunuhnya al-Ḥusain ibn 'Alī ibn Abū Ṭālib (680 M) dalam pertempuran melawan tentara Yazīd ibn Mu'awiyah di tanah Karbala. ${ }^{40}$

Pasca kematian al-Ḥusain ibn 'Alī ibn Abū Ṭālib (680 M), pengikut 'Alī ingin membaiat Muhammad ibn al-Hanafiyyah ${ }^{41}$ sebagai amir. Karena kondisi perpolitikan saat itu tidak stabil, Ibn al-Hanafiyah mengundurkan diri dan memberikan kepemimpinannya pada Yazīd ibn Mu'awiyah. Sebab itulah Ibn alHanafiyah mendapatkan perlakuan istimewa dari penguasa Bani 'Umayyah. Namun setelah Yazīd ibn Mu'awiyah meninggal, Ibn al-Ḥanafiyah terlibat konflik dengan 'Abdullāh ibn Zubair hanya karena Ibn al-Ḥanafiyah tak mau berbaiat kepadanya. 'Abd al-Mālik ibn Marwan, selaku penguasa saat itu, memanfaatkan Ibn al-Hanafiyah untuk bergabung dengannya. Seiring berjalanannya waktu, 'Abd al-Mālik ibn Marwan tidak lagi cocok dengan Ibn al-Ḥanafiyah dan

\footnotetext{
${ }^{40}$ Fathoni, Paham Mahdi Syi'ah dan Ahmadiyah dalam Perspektif, 24.

${ }^{41}$ Ia lebih dikenal sebagai Ibn al-Hanafiyah. Ia adalah putra 'Alī ibn Abi Thalib dari istrinya yang lain, bukan Fatimah binti Muhammad. Ia adalah orang yang dinobatkan oleh kelompok Kaisaniyah sebagai al-Mahdi. Amīn, al-Mahdi wa al-Mahdawiyyah, 10.
} 
kemudian mengusirnya dari wilayahnya. Kejadian itu membuat Ibn alHanafiyah merasa dikhianati. Setiap kali Ibn al-Hanafiyah pindah tempat, selalu mendapatkan perlakuan yang sama, sehingga membuat para pengikutnya, di bawah pimpinan al-Mukhtar ibn 'Ubaid, melakukan pemberontakan terhadap Dinasti yang sedang berkuasa. Al-Mukhtar mengukuhkan Ibn al-Hanafiyah sebagai al-Mahdi untuk memobilisasi masa, dan Ibn al-Ḥanafiyah mengiyakan. ${ }^{42}$

Konflik antara kubu Syi'ah dan kubu 'Umayyah justru dimanfaatkan oleh kubu 'Abbasiyyah untuk membangun kekuasaan. Bani Abbas merasa memiliki hubungan darah dengan keluarga Nabi sehingga mereka membangun koalisi dengan loyalis Ahl al-Bait. Bersama kelompok Syi'ah, loyalis 'Abbasiyyah membuat selogan-selogan apokalipsis -terkait kemunculan Dajjal (Sufyani), alManșūr dan al-Mahdi yang mendorong semangat perjuangan politik Dinasti 'Abbasiyyah. Namun sempat terjadi pemberontakan terhadap penguasa 'Abbasiyyah di Hijaz (762 M) di bawah pimpinan Muhammad ibn 'Abdullāh al-Nafs alZakiya, seorang keturunan Hasan ibn 'Alī yang namanya menjadi ciri-ciri kehadiran al-Mahdi. Keduanya sama-sama menggunakan elemen-elemen millenarianistik, namun dalam perkembangannya mengalami perbedaan signifikan.43

Masa transisi pemerintahan dari Dinasti 'Umayyah ke Dinasti 'Abbasiyyah (pertengahan abad ke-8) merupakan puncak isu millenarianisme dalam Islam. Saat itu sedang terjadi persaingan kekuasaan antara kubu 'Umayyah, 'Abbasiyyah, dan Syi'ah. Kegagalan bidang politik dan militer kelompok Syi'ah selama kurang lebih dua abad, di mana imam-imam mereka selalu menjadi korban kekerasan lawan-lawan politiknya, mengakibatkan penderitaan beruntun dan kekecewaan mendalam sehingga mereka mudah mencerna aqidah al-imāmah, al-mahdiyah, al-raj'ah dan al-ghaibah, ciptaan Ibnu Saba. ${ }^{44}$ Aqidah-

$$
\begin{aligned}
& 42 \text { ولما تحالف العلويون والعباسيون أولا على قتال الأمويين ظهر السفاح بنظرية جديدة: وهي أن محمد ابن الحنفية }
\end{aligned}
$$

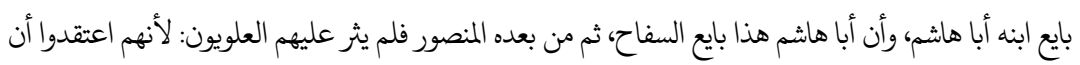

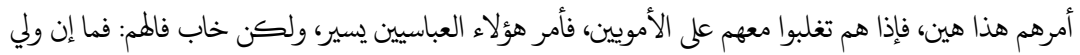

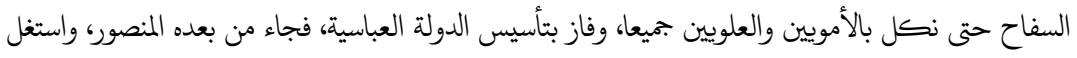

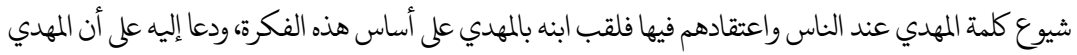

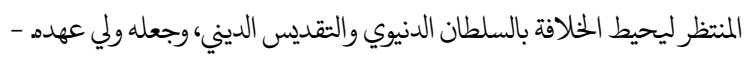

Amīn, 11; Rahman, Islam, 273.

43 Livne-Kafri, "Some Notes on the Muslim Apocalyptic Tradition," 89.

44 Fathoni, Paham Mahdi Syi'ah dan Ahmadiyah dalam Perspektif, 42-8 dan 149. 
aqidah tersebut menjadi faktor dominan dalam mempercepat proses lahirnya sikap menunggu-nunggu kehadiran kembali imam mereka (al-Mahdi alMuntazar) sebagai Messiah yang akan memperbaiki tatanan kehidupan sosial mereka. ${ }^{45}$

Dalam kondisi terpojok, loyalis Ahl al-Bait didukung oleh kaum Mawālli (bangsawan) Persia -dulunya didominasi pengikut Nasrani dan Yahudi- yang merasa tidak cocok dengan pemerintahan Bani 'Umayyah untuk melakukan perlawanan-perlawanan. Mereka memberikan arah baru gerakan sosio-politik Ahl al-Bait yang banyak dipengaruhi oleh pikian-pikiran asing Persia. Konsekuensinya terjadi perubahan pada arah gerakan politik Ahl al-Bait menjadi gerakan keagamaan yang bercorak kemazhaban. ${ }^{46}$ Dengan disertai pelbagai tekanan yang kuat, loyalis Ahl al-Bait terdorong untuk menciptakan ide-ide penyemangat untuk melawan tirani yang sedang dideritanya dengan label agama. Inilah titik awal millenarianisme dalam Islam yang sangat dipengaruhi oleh millenarianisme Yahudi dan Nasrani dari Persia. ${ }^{47}$ Banyak mantan agamawan mereka yang terlibat dalam periwayatan hadis-hadis israiliyyat dan futuristik, seperti Ka'ab al-Ahbār (Yahudi Yaman), Hudaifah ibn al-Yaman, alWalid ibn Muslim dan Wahb ibn Munabbih (Nasrani Arab Selatan). Berikut salah satu riwayat dari Ka'ab al-Ahbar:

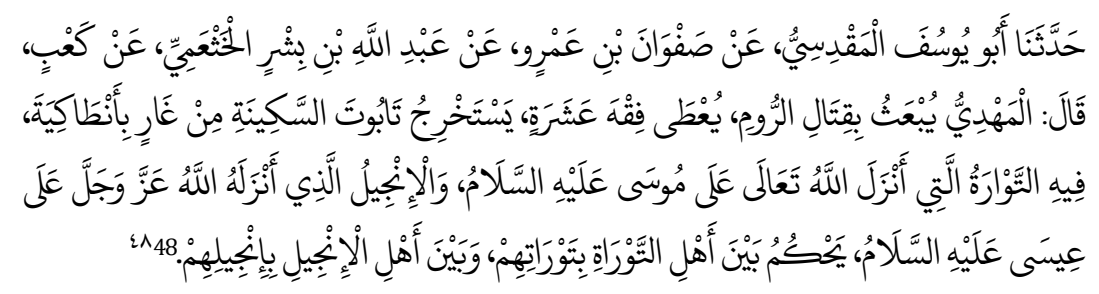

Kasus yang dialami loyalis Ahl al-Bait (didominasi pengikut Syi'ah) adalah salah satu contoh sejarah perkembangan ideologi yang bersamaan dengan isu politik. Syi'ah merasa terdeprivasi dan terganggu kulturnya sehingga memunculkan suatu gerakan revolusi millenarian. Ideologi ini selalu tampil dalam

${ }^{45}$ Fathoni, 19; Jean-Pierre Filiu, "The Return of Political Mahdism'," in Current Trends in Islamist Ideology, vol. 8, 2009, 27-8; R. Stephen Humphreys, Islamic History: A Framework for Inquiry, Revised (Princeton: Princeton University Press, 1991), 109-10.

46 Rahman, Islam, 171.

47 Fathoni, Paham Mahdi Syi'ah dan Ahmadiyah dalam Perspektif, 8 dan 154-5.

48 al-Khuzai, Kitāb al-Fitan, 2:hd. 1022.

JURNAL THEOLOGIA — Volume 30, No. 2, December 2019 
pergolakan di tengah-tengah revolusi suatu masyarakat, yang mana sistem ekonomi, psikis, organistik, etis, maupun status sosialnya tertekan..$^{49}$ Deprivasi yang ada sebenarnya adalah persoalan di internal gerakan yang prosesnya hanya dirasakan oleh pengikutnya saja. Tidak ada satupun lembaga lain yang mampu mengatasi deprivasi itu kecuali oleh kelompok itu sendiri. Transmisi deprivasi pada suatu masyarakat berlangsung cukup lama dan bisa dialami oleh beberapa generasi dari kelompok masyarakat tersebut. ${ }^{0}$ Karena itu, segala bentuk ketegangan dan kekuatiran yang terjadi pada masyarakat justru diakibatkan oleh tradisi pemikiran millennial itu sendiri, sehingga melahirkan millenarianisme sebagai bentuk pelipur hati yang sempurna. ${ }^{51}$

\section{E. Persebaran Mahdiisme dan Relasinya terhadap Perkembangan Hadis-hadis Mahdawiyah}

Ideologi millenarian oleh Humphreys dikatakan utopis. Masing-masing kelompok boleh mengklaim harapan merekalah yang kelak akan membangun tatanan sosial terbaik, tatanan yang benar dan tatanan yang legitimate bagi semua orang, namun tetap tidak mengesampingkan harapan-harapan dari kelompok lain. Tujuan utopis sering mengarah pada pembentukan kembali masa keemasan yang pernah terjadi pada masa lalu namun saat ini hilang (romantisisme), atau mengarah pada usaha merealisasikan mimpi dan aspirasi yang dibayangkan pada masa lalu. Ideologi ini bersifat siklis dan menuntut adanya perubahan radikal dalam mewujudkan tatanan. ${ }^{52}$ Ideologi ini secara sosial memang sengaja diciptakan, diatur dan disebarluaskan untuk mengontrol umat, bahkan kalau perlu diubah menjadi system of belief untuk memistifikasi sistem politik serta mengaburkan peristiwa-peristiwa politis yang sebenarnya terjadi..$^{53}$

${ }^{49}$ Charles Y. Glock dan R. Stark, “On the Origin and Evolution of Religious Groups (1965)," in Sociological Perspective, Selected Reading, Ed. Kenneth Thomson dan Jeremy Tunstall (Middlesex: Penguin Education, 1979), 392-96; Abdul Aziz, Varian-Varian Fundamentalisme Islam di Indonesia (Jakarta: Diva Pustaka, 2004), 2.

${ }^{50}$ Nicholas Abercrombie, The Penguin Dictionary of Sociology (England: The Penguin Books Ltd., 1984), 66.

${ }^{51}$ Chon, "Milleniarisme Zaman Pertengahan: Hubungannya dengan Studi Komparatif Gerakangerakan Millenarian," 29-30.

52Humphreys, Islamic History: A Framework for Inquiry, 148.

${ }^{53}$ Muhyar Fanani, Metode Studi Islam; Aplikasi Sosiologi Pengetahuan sebagai Cara Pandang (Yogyakarta: Pustaka Pelajar, 2008), 42. 
Suatu gerakan sosial agar bisa mendapatkan dukungan dan partisipasi dari masyarakat harus membingkai (frame) argumentasi ideologinya ${ }^{54}$ Agama merupakan salah satu legitimasi yang efektif dalam kehidupan sosial dan budaya. ${ }^{55}$ Dalam setiap sejarah peradaban keagamaan selalu diperkenalkan sejumlah gerakan keagamaan lengkap dengan ideologi dan dasar-dasar legitimasinya. Fenomena gerakan keagamaan tersebut muncul sebagai reaksi atas pelbagai tantangan yang dihadapi atau sebagai akibat dari tekanan eksternal. Oleh karena itu, persoalan penting sesungguhnya adalah bagaimana tantangan itu memuluskan jalan bagi munculnya gerakan keagamaan sekaligus bagaimana gerakan agama itu memperoleh legitimasi dari teks agamanya. ${ }^{56}$ Gerakan millenarianisme Islam yang diwujudkan dalam kehadiran al-Mahdi justru sama sekali tidak mendapatkan legitimasi dari teks al-Qur'an, sementara al-Qur'an sudah sedemikian rupa terbakukan dalam bentuk al-mushafal-utsmani, sehingga satusatunya jalan untuk melegitimasi millenarianisme adalah melalui teks hadis.

Kontroversi agama, perselisihan kepemimpinan, percekcokan antar suku dan perbedaan lokal merupakan pemicu utama dalam penciptaan dan penyebaran tradisi millenarian. ${ }^{57}$ Humphreys mengatakan bahwa kelompok Syi'ah menggunakan hadis-hadis mahdawiyyah untuk kepentingan perlawanan menuntut hak legitimasi kekhilafahan. ${ }^{58}$ Tampaknya tokoh-tokoh Syi'ah kualahan menghadapi krisis yang dialami kelompoknya. Kondisi ini menuntut para pimpinan Syi'ah membuat ideologi hegemonik untuk membakar semangat pengikut-pengikutnya. Mereka menjadikan hadis sebagai cara untuk menghegemonikan ideologi. ${ }^{59}$ Ahmad Amīn menambahkan bahwa mahdiisme ini di-

${ }^{54}$ M. Imam Aziz, "Memahami Gerakan Islam: Sebuah Agenda Untuk Indonesia," dalam Gerakan Sosial Islam: Teori, Pendekatan, dan Studi Kasus, Ed. Quintan Wiktorowicz (Yogyakarta: Gading Publishing, 2012), 6.

${ }^{55}$ Reza Wattimena, Melampaui Negara Hukum Klasik (Locke - Rousseau - Habermas) (Yogyakarta: Kanisius, 2007), xi.

${ }^{56}$ Rusydi Sulaiman, Pengantar Metodologi Studi Sejarah Peradaban Islam (Jakarta: Raja Grafindo Persada, 2014), 87.

${ }^{57}$ Livne-Kafri, "Some Notes on the Muslim Apocalyptic Tradition," 80.

${ }^{58}$ Humphreys, Islamic History: A Framework for Inquiry, 11; Fathoni, Paham Mahdi Syi'ah dan Ahmadiyah dalam Perspektif, 5-7.

${ }^{59}$ Teori hegemoni Gramscy menyatakan bahwa suatu ideologi bisa saja diterapkan secara hegemonik untuk menguatkan ideologi gerakan serta membentung kekuatan lawan dalam sebuah evolusi. Martin Clark, Antonio Gramsci and the Revolution that Failed (New Haven: Yale University Press, 1977), 2-4. 
tanamkan dalam bentuk perlawanan terhadap rezim Dinasti 'Umayyah. ${ }^{60}$ Sebagai langkah konkret, mereka pun membuat ideologi utopis melalui hadishadis yang mengatakan bahwa kemenangan ada di bawah pimpinan keturunan mereka, yang mereka sebut al-Mahdi.

Kefanatikan kelompok Syi'ah terhadap al-Mahdi dibuktikan dengan banyaknya hadis-hadis mahdawiyyah ditemukan dalam kitab Syi'ah. Misalnya, dalam al-Käfi li al-Kulaini disebutkan:

$$
\begin{aligned}
& \text { علي بن محمد، عن عبدالله بن محمد بن خالد قال: حدثني منذر بن محمد بن قابوس، عن منصور }
\end{aligned}
$$

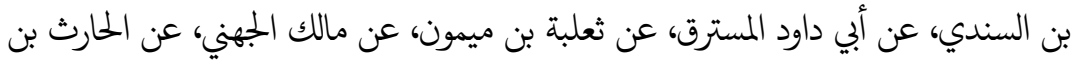

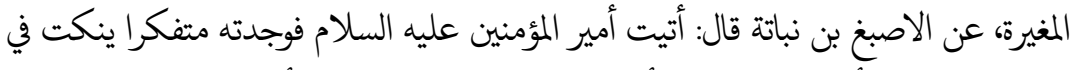

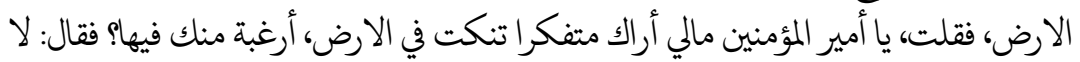

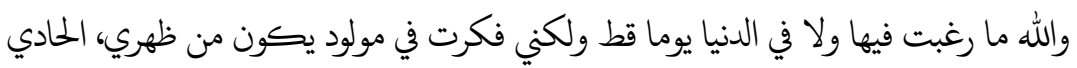

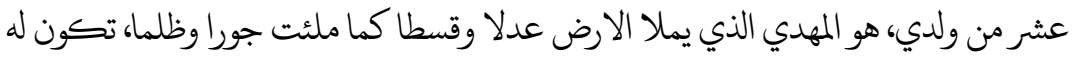

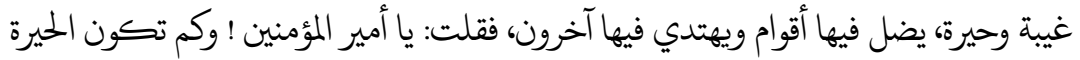

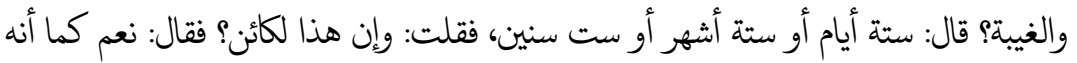

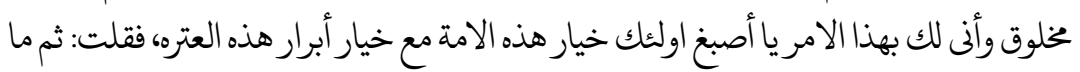

$$
\begin{aligned}
& \text { يكون بعد ذلك فقال: ثم يفعل الله ما يشاء فإن له بداء ات وإرادات هذات وغايات الإنة ونهايات }
\end{aligned}
$$

${ }^{60}$ Amīn, al-Mahdi wa al-Mahdawiyyah, 5 dan 11.

${ }^{61} \mathrm{Abū}$ Ja'far Muhammad ibn Ya'qūb ibn Ishāq al-Kulaini al-Rāzī, al-Kāfi li al-Kulaini, Ed. Alī Akbar al-Ghifarī, vol. 1 (Teheran: Dār al-Kutub al-Islāmī, 1363), 1/338;

Hadis ini memiliki kemiripan redaksi (dengan beragam varian bentuk teksnya) dengan hadishadis yang diriwayatkan kelompok Sunni. Misalnya dari Musnad Abū Dāwud (4285) dan alMustadrak'alā al-Șahīhaini li al-Hākim :

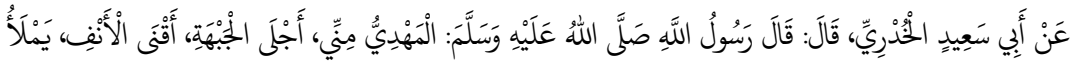

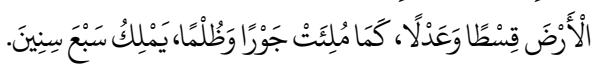

Sulaimān ibn Dāwud al-Tayālisī al-Bașrī Abu Dāwud, "Bāb al-Mahdi," in Sunan Abū Dāwud, Ed. Muhammad ibn 'Abd al-Muhsin al-Turkiy (Mesir: Dār Hijir, 1999); Abu Abdillāh Muhammad ibn 'Abdullāh al-Ḥākim al-Nisāburī, al-Mustadrak 'alā al-Ṣaḥị̣aini, Ed. Muștâāa 'Abd al-Qādir 'Ața (Beirut: Dār al-Kutub al-'Ilmiyyah, 1990);

Dalam Musnad Ahmad ibn Hanbal (11212), Mușannafibn Abī Shaibah, Sunan Ibn Mājah, dan alFitan disebutkan: 
Dalam bab lain disebutkan:

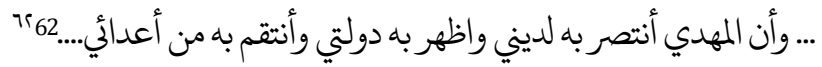

Syi'ah Imamiyah adalah kelompok terbesar yang fanatik pada mahdiisme. Kelompok ini terbagi menjadi dua golongan; pertama, Syi'ah Sab'iyyah atau dikenal dengan Ismāîliyah atau Batiniah yang merepresentasikan mahdiisme lebih realistis, yakni "Abdullāh ibn Muḥammad ibn al-Ḥasan ibn 'Alī ibn Abū Țālib yang telah berhasil mendirikan dinasti di Maghrib (Afrika). Kedua, kelompok yang meyakini putra Ḥasan al-Askarī (imam Syi’ah ke-11), Muḥammad ibn Ḥasan al-Askarī, sebagai Imam al-Mahdi. Sayangnya keberadaan tokoh itu adalah fiktif, karena Hasan al-Askarī ternyata tidak memiliki putra atau dibilang hilang secara misterius. ${ }^{63}$ Dari kasus ini terdapat banyak riwayatriwayat yang menerangkan tentang kemisteriusannya di dalam kitab al-Kāfi alKulaini. Inilah awal ideologi al-raj'ah. ${ }^{64}$ Kebanyakan riwayat bercorak politis karena menunjukkan bahwa Imam al-Mahdi berasal dari Ahl al-Bait sendiri yang kelak akan membalaskan para pembunuh al-Ḥusein ibn 'Alī ibn Abū Tālib.

Keberadaan hadis-hadis mahdawiyyah menjadikan kelompok Syi'ah cepat menguasai teologi mahdiisme umat Islam. Golongan non-Syi'ah pun tidak ketinggalan 'membuat' hadis-hadis mahdawiyyah dengan versi lain sesuai dengan identitas golongannya masing-masing. Sunni adalah salah satu sekte yang fanatik terhadap kedatangan al-Mahdi. Menariknya, kitab Șaḥị̣ al-Bukhārī dan Șahịh

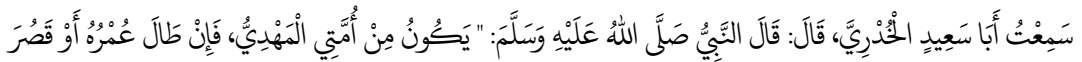

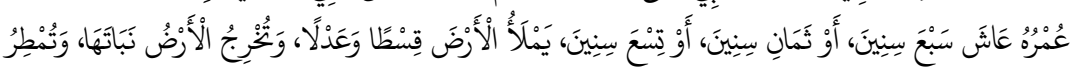

$$
\begin{aligned}
& \text { السَّمَاءُ قَطْرَهَها. }
\end{aligned}
$$

Menurut kritikus hadis di kalangan Sunni, kualitas hadis ini adalah hasan li ghairih, karena banyak shawāhid-nya. Abū 'Abdullāh Aḥmad ibn Muhammad al-Shaibāni ibn Ḥanbal, al-Musnad alImām Ahmad ibn Hanbal, Ed. Shu’aib al-Arna'ūte (Beirut: Mu’assasah al-Risālah, 2001); Abū Bakar al'Abbasiy ibn Abī Shaibah, Musannaf Ibn Abī Shaibah, Ed. Kamāl Yūsūf al-Hūt (Riyāz: Maktabah alRashd, 1409); Abū 'Abdullāh Muḥammad ibn Yazīd al-Qazwīnī Ibn Mājah, "Bāb Khurūj al-Mahdi," dalam Sunan Ibn Mājah, Ed. Muhammad Fuad 'Abd al-Bāqi (Cairo: Dār Ihyā' al-Kutub al-Arabiyyah, n.d.); al-Khuzai, Kitāb al-Fitan.

62al-Rāzī, al-Käfi li al-Kulaini, 1:2/11.

63Fathoni, Paham Mahdi Syi'ah dan Ahmadiyah dalam Perspektif, 4.

${ }^{64}$ Yakni al-ghaibah al-kubrā dan al-ghaibah al-sughrā. Lihat: Filiu, "The Return of Political Mahdism,", 28.

JURNAL THEOLOGIA — Volume 30, No. 2, December 2019 
Muslim yang menjadi kitab hadis induk kaum Sunni justru tidak meriwayatkan kedatangan al-Mahdi. Kenyataan ini mengundang kecurigaan terkait kelemahan hadis-hadis mahdawiyyah. Benar, al-Zahabi secara spesifik memberikan catatancatatan terkait kelemahan hadis-hadis mahdawiyyah yang ada dalam kitab al-'Ilal al-Mutānahiyah karya Ibnu al-Jauzi. Di dalamnya dijelaskan adanya perawiperawi yang dâîf (lemah) atau majhūl (tidak diketahui). ${ }^{65}$ Selanjutnya, dengan mengutip pendapat Ibnu Hajar, Ahmad Amin mengatakan ada sekitar 50 hadis bermasalah tentang al-Mahdi. ${ }^{66}$ Amin menambahkan bahwa hadis-hadis mahdawiyyah, terutama versi Syi'ah, mengandung cerita bohong, sebab di dalamnya dipenuhi cerita-cerita aneh dan kabar gaib tentang peristiwa zamannya, apalagi terdapat ramalan yang tertulis di kulit lembu tentang peristiwa yang akan dialami oleh Ahl al-Bait Cerita tersebut diriwayatkan oleh Ja'far al-Ṣadiq.67

Tsamir Hasyim al-Amidy melalui karya "al-Mahdi al-Muntazar fi Fikri alIslām" membantah pernyataan Ahmad Amin. Ia menyatakan bahwa hadis-hadis mahdawiyyah adalah șahịh (otentik) sekaligus mutawātīr (banyak jalur tersambung) hingga Nabi Muhammad. Ia pun menguatkan bahwa al-Qur'an sebenarnya sudah mensinyalir kemunculan al-Mahdi sebagaimana tafsiran alṬabārī. Demikian juga Ṣaḥịh al-Bukhāri dan Șaḥịh Muslim pun sudah menyebutkan ciri-cirinya, hanya saja tidak menyebutkan namanya secara ekspisit, tetapi dengan kata al-imām. ${ }^{68}$

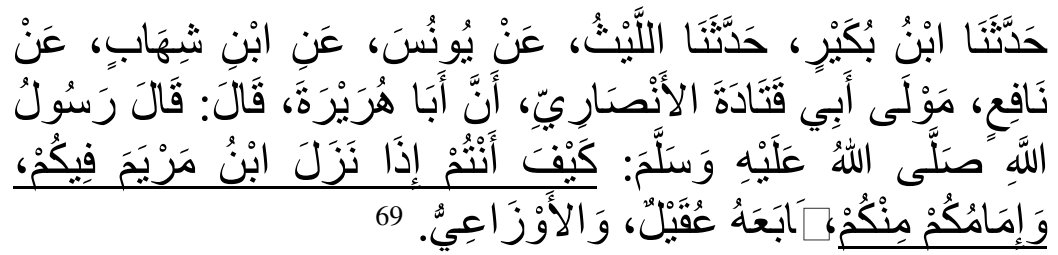

${ }^{65}$ al-Ẓahabī, Talkhīs Kitāb al-Ilal al-Mutanāhiyah li Ibn al-Jauzī, 311-21.

${ }^{66}$ Amīn, al-Mahdi wa al-Mahdawiyyah, 48.

${ }^{67}$ Aḥmad Amīn, Duhạa al-Islām, vol. 3 (Cairo: Maktabah al-Nahḍah al-Miṣriyah, n.d.), 243.

68 Sayyid Tamir 'Hashim al-'Amidy, al-Mahdi al-Muntaẓar fi Fikr al-Islāmy (Qom: Markaz alRisālah, 1425), 19-30.

${ }^{69} \mathrm{Abū}$ Abdillāh Muhammad ibn Ismāīl al-Bukhārī, al-Jāmi' al-Ṣaḥịh li al-Imām al-Bukhārī (Beirut: Dār Tauq al-Najāh, 1422), hd. 3449; Muslim ibn al-Hajāj Abū al-Hasan al-Qushairī alNisāburī, "Bāb al-Imārah," dalam a-Musnad al-Șahīh al-Mukhtașar Șahịhh Imām Muslim, vol. 3 (Beirut: Dār Ihyā' al-Turath al-'Arabī, n.d.), hd. 244, 245 dan 246. 
Terdapat satu hadis yang secara spesifik menggunakan bentuk jamak dari kata al-Mahdi. Kata al-Mahdiyyun disandarkan pada kalimat al-Khulafa alRasyidun mengarah pada pemaknaan level spiritual, yakni bagi mereka yang mendapat hidayah dari Allah dan memiliki kedekatan dengan Nabi. Mereka adalah Abū Bakar (w. 13/634), 'Umar ibn Khațāb (w. 23/644), 'Uthmān ibn 'Affān (w. 35/656), dan 'Alī ibn Abū Țālib (w. 40/661). Dalam perkembangannya, penggunaan kata 'al-Mahdi' justru ditafsirkan sebagai oknum-oknum tertentu.

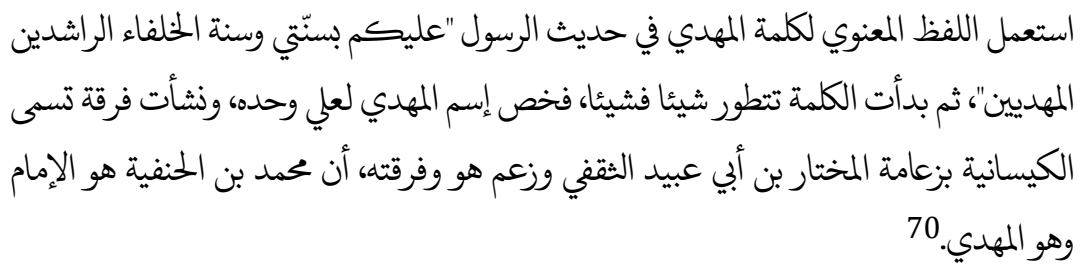

Salah satu tokoh yang menjadi kunci dalam mencari akar kesejarahan hadis-hadis mahdawiyyah adalah Ka'ab al-Ahbar (w. 10/632), seorang mantan agamawan Yahudi yang telah masuk Islam dan tinggal di Madinah. Dialah yang menarasikan beberapa hadis eskatologis yang menjadi referensi tentang alMahdi. Merujuk pada sejarah permulaan Islam, Ka'ab dianggap sebagai orang yang mengatakan bahwa Muhammad ibn al-Ḥanafiyah adalah al-Mahdi. ${ }^{71}$ Sementara Muhammad ibn al-Hanafiyah sendiri terlibat banyak dalam periwayatan beberapa hadis mahdawiyyah, baik dalam tradisi Syi'ah maupun Sunni. Berikut salah satu hadis yang diriwayatkan oleh Muhammad ibn alHanafiyah tentang asal al-Mahdi dari Ahl al-Bait:

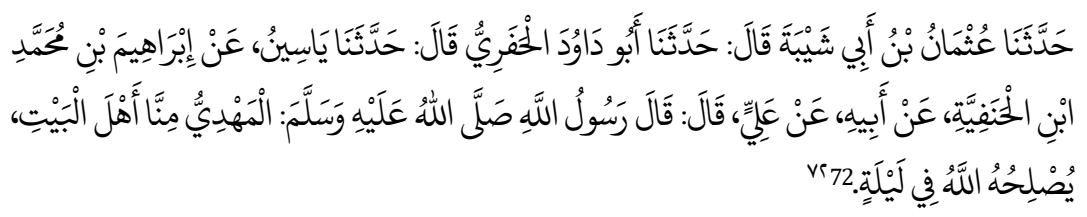

${ }^{70}$ Muhammad Mahjūb Mālik, al-Muqāwamah al-Dākhiliyyah li Harakati al-Mahdiyyah (Beirut: Dār al-Jail, 1987), 18; Amīn, al-Mahdi wa al-Mahdawiyyah, 9-10.

${ }^{71}$ Saritoprak, "The Mahdī Tradition in Islam: A Social-Cognitive Approach," 664; Abū al-Faraj 'Alī ibn al-Ḥusain al-Asbahāni, Kitāb al-Aghānī, vol. 8 (Cairo: Dār al-Ṭiba'ah al-Amiriyah, 1825), 8/33.

72 Ibn Mājah, "Bāb Khurūj al-Mahdi," hd. 4084; Ibn Ḥanbal, al-Musnad al-Imām Ahmad ibn Hanbal, hd. 645; Ibn Abī Shaibah, Muṣannaf Ibn Abi Shaibah, hd. 37644. 
Keterlibatan Muhammad ibn al-Hanafiyyah ibn 'Alī, tokoh Syi'ah, dalam riwayat hadis Sunni adanya pengaruh ideologi Syi'ah yang tertanam dalam ideologiSunni.

Ka'ab al-Aḥbar dan Muhammad ibn al-Ḥanafiyah adalah orang-orang yang sering terlibat dalam periwayatan hadis-hadis mahdawiyyah. ${ }^{73}$ Di antara hadishadis yang diriwayatkan adalah tentang kelahiran al-Mahdi dari keluarga Abbas atau dari nasab Fatimah binti Muhammad dan nama aslinya sama dengan Nabi, yakni Muhammad ibn 'Abdullāh. Kemudian hadis tentang ciri-ciri al-Mahdi yang akan keluar dari timur dengan membawa bendera hitam, sehingga ada perintah untuk berbaiat padanya. al-Mahdi akan memusatkan pemerintahannya di Damaskus dan bersama pengikutnya akan berperang melawan salib. ${ }^{74} \mathrm{Di}$ sisi lain, Ka'ab juga terlibat dalam periwayatan tentang kehadiran Dajjal/Sufyani. ${ }^{75}$ Dajjal disebutkan sebagai putra dari perempuan Kalbiyah, padahal ibu dari Yazīd ibn Mu'awiyah dan putranya (Muawiyah ibn Yazīd) adalah perempuan Kalbiyah. Karena itu, riwayat tentang Dajjal/Sufyani vis a vis dengan riwayat alMahdi sebenarnya merupakan skenario konflik antara kubu 'Umayyah dan 'Abbasiyyah, di mana Dajjal digambarkan sebagai kubu 'Umayyah yang akan dikalahkan oleh al-Mahdi dan Isa (manifest dari kubu 'Abbasiyyah).

A tradition in Nu'aym's book refers to a man who will come to power (yamliku), whose name is 'Abd Allah b. Yazid, the son of Kalbite women ( $i b n$ al-kalbiyya) who will be al-sufyānī. This reflects a historical background that might also suit the Beth Shan tradition, because the mother of the Umayyad caliph Yazīd b. Mu'âwiya and the mother of his son Mu'āwiya b. Yazīd were Kalbite women. In another tradition, the Sufyānī will come from almandarûn, east of Beth Shan, wearing a crown, a symbol of kings, which might be connected with earthly rule, kingdom (mulk) at tributed negatively to the Umayyads. This tradition might refer to the first 'Abbāsid period because its Sufyāni will fight the Black Banners (the symbol of the 'Abbâsid uprising against the Umayyads), and even to revolts of Sufyānīs, having pro-Umayyad sentiments. If so, this suggests more than one

73 Baca buku "al-Fitan li Nuaim ibn Hammad" karya Abu Abdullah Nuaim ibn Hammad ibn Muawiyah ibn al-Haris al-Khuza'I. buku tersebut secara khusus menyebutkan hadis-hadis yang berkaitan dengan teologi apokalipsis Islam, mulai dari kemunculan Dajjal hingga keluarnya al-Mahdi.

74 Yaocof, Concepts of Messiah: A Study of the Messianic Concepts of Islam, Judaism, Messianic Judaism, Christianity, 12.

${ }^{75}$ Al-Khuzai, Kitāb al-Fitan, 2:hd. 1447. 
historical settine, when an element of an older apocalypse is used in a later apocalyptic tradition. ${ }^{76}$

Karena itu, hadis tentang munculnya kelompok-kelompok dari arah timur dengan membawa bendera hitam sangat popular dalam penggambaran alMahdi. Di bawah pimpinan al-Mahdi, mereka melakukan penyerangan terhadap tirani-tirani di muka bumi, maka sangat dianjurkan bagi setiap Muslim untuk berbaiat kepadanya.

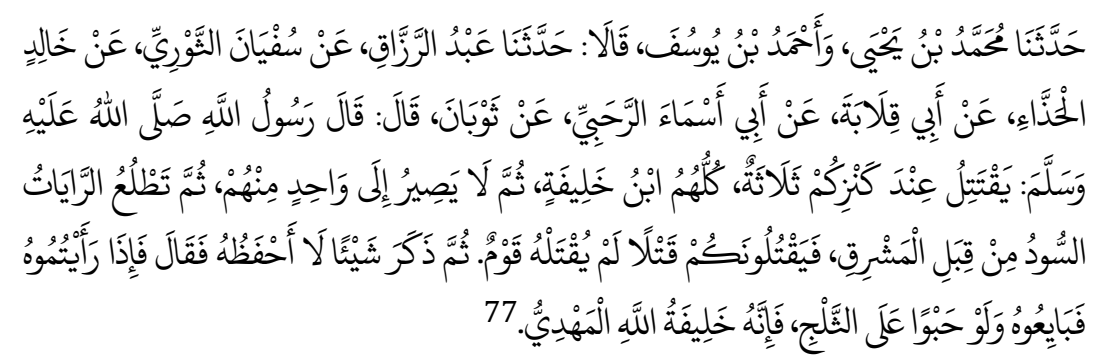

Dengan melihat struktur dan pola teks hadis, kita akan menemukan beragam teks yang hampir sama beserta penambahan-penambahan informasi di dalamnya. ${ }^{78}$ Banyak kritikus hadis yang menyatakan hadis tersebut bermasalah, baik dari sisi kridibilitas perawi maupun matannya. Hadis semacam inilah yang berpotensi menjadi dasar radikalisme gerakan Islam saat ini. Tercatat ada nama Mirza Ghulam Ahmad (w. 1908 M) yang diklaim kelompok Ahmadiyah sebagai al-Mahdi atau Nabi, gerakan ISIS mengklaim Abū Bakar alBaghdadi sebagai al-Mahdi yang membawakan bendera hitam, dan gerakan Mahdi di Sudan yang mengklaim Muḥammad Aḥmad ibn 'Abdullāh al-Mahdi (w. 1881 M), keturunan Rasulullah, sebagai Imam Mahdi yang dijanjikan.79

${ }^{76}$ Ofer Livne-Kafri, "Some Observations on the Migration of Apocalyptic Features in Muslim Tradition," Acta Orientalia Academiae Scientiarum Hungaricae 60, no. 4 (2007): 474, https://doi.org/ $10.2307 / 23658770$.

77Ibn Mājah, "Bāb Khurūj al-Mahdi,” hd. 4084.

78 Ibn Mājah, "Bāb Khurūj al-Mahdi", hd. 4082, 4084; al-Khuzai, Kitāb al-Fitan, hd. 555, 562, 570, 584, 906, 907, 895, 1975; Ibn Abī Shaibah, Muṣannaf Ibn Abì Shaibah, hd. 37727; al-Nisāburī, alMustadrak 'alā al-Ṣaḥịhaini, hd. 8483; Abū Bakr Ahmad ibn al-Ḥusayn ibn 'Alī al-Bayhaqī. al-Sunan alKubrä," vol. 2, 2003., hd. 13068.

${ }^{79}$ Muhammad Rikza Muqtada, "Radicalism in Islam: The Politicization of the Mahdawiyyah Hadith among the Mahdi Movement," Kalam 13, no. 1 (2019): 85-112, https://doi.org/10.24042/ klm.v13i1.4069. 
Karena tercantum dalam beberapa kitab kompilasi hadis, khususnya $b a b$ al-Fitan wa al-Malāhim dan bab khurüj al-Mahdi, 'hadis-hadis bermasalah' tersebut justru memperoleh statusnya hingga pada level mutawātir dan bisa dibilang otentik ${ }^{80}$ Proses demikian terjadi karena adanya konsensus (ijma) di kalangan muhaddithin dalam mengalihbentukkan kualitas hadis supaya bisa diterima. Syi'ah dan Sunni merupakan dua sekte Islam terbesar yang memiliki intensi dalam pengkajian hadis dengan tradisi yang berbeda. Konsekuensinya ide-ide dari mereka banyak mempengaruhi nalar teologis sekte-sekte Islam. Meskipun begitu, pandangan Sunni lebih mendominasi pemikiran sekte-sekte Islam, seperti Ahmadiyah, ISIS dan beberapa aliran Islam lokal yang cukup banyak pengikutnya. Hal ini dikarenakan kitab-kitab hadis tradisi Sunni menjadi rujukan oleh kelompok-kelompok tersebut.81 Bob de Graaff pun menyatakan:

Although it is commonly believed that the Mahdi is a specifically Shi'ite element in Islam, throughout history there have been more Sunnite Mahdis and among current Islamic apocalyptic writings, the majority is from a Sunni point of view. 82

Meskipun hadis kalangan Sunni lebih berpengaruh terhadap sekte-sekte Islam, kelompok Syi'ah-lah yang paling fanatik dalam mahdiisme. ${ }^{83} \mathrm{Hal}$ ini karena pengaruh dari sejarah panjang kelompok Syi'ah yang selalu mengalami penindasan oleh rezim di masanya.

\section{F. Kesimpulan}

Teologi Islam tidak sepenuhnya murni dogmatik dari al-Qur'an dan hadis, tetapi terdapat proses manusiawi. Kasus mahdiisme ini terjadi seputar peristiwa transisi kekuasaan dari Dinasti 'Umayyah kepada Dinasti 'Abbasiyyah, di mana selalu melibatkan pengikut-pengikut Syi'ah sebagai korban politik. Per-

${ }^{80}$ Dalam kasus hadis-hadis yang bermasalah tentang penasakhan ayat wasiat oleh ayat waris, David S. Power menjelaskan bahwa hadis yang semula bermasalah pada akhirnya menjadi kuat karena kemutawatirannya. Hal tersebut dibuktikan dengan banyaknya perawi yang meriwayatkan hadis tersebut. Dalam hal ini, terjadi kasus serupa tentang penguatan hadis-hadis mahdawiyyah yang bermasalah dengan menaikkan statusnya menjadi mutawatir. Lihat: Powers, Studies in Qur'an and Hadith: The Formation of the Islamic Law of Inheritance, 70.

${ }^{81}$ Alasannya adalah kitab-kitab induk hadis, seperti Kutub al-Sittah, Musnad, dan Muṣannafät, juga dijadikan rujukan oleh sekte-sekte tersebut.

${ }^{82}$ Bob de Graaff, "History of Fanaticism: From Enlightenment to Jihad," in AARHUS Lecture Series 2010, 2010, 16.

83Saritoprak, "The Mahdī Tradition in Islam: A Social-Cognitive Approach," 673-74. 
singgungan kaum Syi'ah dengan mantan agamawan Yahudi dan Nasrani pada masa konflik saat itu memberikan pengaruh terhadap corak teologi Syi'ah. Kaum Syi'ah mempropagandakan akan kehadiran al-Mahdi sebagai sosok penyelamat dari keturunan Ahl al-Bait dengan membuat kemudian mengembangkan hadishadis mahdawiyyah. Di sini, kemunculan mahdiisme seiring dengan kemunculan hadis-hadis mahdawiyyah. Di antara para perawi hadis mahdawiyyah adalah mantan agamawan Yahudi (Ka'ab al-Ahbar) dan Nasrani (Wahb ibn Munabbih).[]

\section{DAFTAR PUSTAKA}

Abercrombie, Nicholas. The Penguin Dictionary of Sociology. England: The Penguin Books Ltd., 1984.

Abū Dāwud, Sulaiman ibn Dāwud al-Ṭayālisī al-Bașrī. "Bāb al-Mahdi." Dalam Sunan Abū Dāwud, Ed. Muhammad ibn Abdul Muhsin al-Turkiy. Mesir: Dār Hiijr, 1999.

al-'Amidy, Sayyid Tamir 'Hashim. al-Mahdi al-Muntazar fi Fikr al-Islāmy. Qom: Markaz al-Risālah, 1425.

Amin, Aḥmad. Duḥā al-Islām. Vol. 3. Cairo: Maktabah al-Nahḍah al-Mișriyah, n.d.

Amīn, Ahmad. al-Mahdi wa al-Mahdawiyah. Cairo: Muassasah Handawi li alTa'lìm wa al-Thaqafah, 2012.

al-Asbaḥāni, Abū al-Faraj 'Alī ibn al-Husain. Kitāb al-Aghānī. Vol. 8. Cairo: Dār alȚiba'ah al-Amiriyah, 1825.

Aziz, Abdul. Varian-Varian Fundamentalisme Islam di Indonesia. Jakarta: Diva Pustaka, 2004.

Aziz, M. Imam. "Memahami Gerakan Islam: Sebuah Agenda Untuk Indonesia." Dalam Gerakan Sosial Islam: Teori, Pendekatan, dan Studi Kasus, Ed. Quintan Wiktorowicz. Yogyakarta: Gading Publishing, 2012.

al-Bayhaqī, Abū Bakr Aḥmad ibn al-Ḥusayn ibn 'Alī. al-Sunan al-Kubrā. Makkah: Dār al-Bāz, 2003.

al-Bukhārī, Abū Abdillāh Muhammad ibn Ismāâil. al-Jāmi' al-Ṣaḥịḥ li al-Imām alBukhārī. Beirut: Dār Ṭauq al-Najāh, 1422. 
Brisbois, Michael J. "Millenarian Moderns: A Study of Utopian Desire." University of Calgary, 2013. https://doi.org/10.11575/PRISM/26918.

Chon, Norman. "Milleniarisme Zaman Pertengahan: Hubungannya dengan Studi Komparatif Gerakan-gerakan Millenarian." Dalam Gebrakan Kaum Mahdi: Studi tentang Gerakan-Gerakan Keagamaan Revolusioner, Ed. Sylvia L. Thrupp dan Tohiruddin Lubis, terj. Anas Muhyiddin. Bandung: Pustaka, 1984.

Clark, Martin. Antonio Gramsci and the Revolution that Failed. New Haven: Yale University Press, 1977.

Cook, David. Contemporary Muslim Apocalyptic Literature. Syracuse, NY: Syracuse University Press, 2008.

- _- '"Hadith', Authority and the End of the World: Traditions in Modern Muslim Apocalyptic Literature." Oriente Moderno 21, no. 82 (2002): 31-53. https://www.jstor.org/stable/25817811.

Delitzsch, Franz. Messianic Prophecies in Historical Succession. New York: Charles Scribner's Sons, 1891.

Doi, A. R. I. "The Yoruba Mahdi." Journal of Religion in Africa 4, no. 2 (1971): 11936. https://doi.org/10.2307/1594738.

Fanani, Muhyar. Metode Studi Islam; Aplikasi Sosiologi Pengetahuan sebagai Cara Pandang. Yogyakarta: Pustaka Pelajar, 2008.

Fathoni, Muslih. Paham Mahdi Syi'ah dan Ahmadiyah dalam Perspektif. Jakarta: Raja Grafindo Persada, 1994.

Filiu, Jean-Pierre. "The Return of Political Mahdism'." Dalam Current Trends in Islamist Ideology, 8:26-38, 2009.

Garaudy, Roger. Zionis Sebuah Gerakan Keagamaan dan Politik. Terj. Moelia Radja Siregar. Jakarta: Gema Press Insani, 1995.

Glock, Charles Y., dan R. Stark. "On the Origin and Evolution of Religious Groups (1965)." Dalam Sociological Perspective, Selected Reading, Ed. Kenneth Thomson dan Jeremy Tunstall. Middlesex: Penguin Education, 1979.

Graaff, Bob de. "History of Fanaticism: From Enlightenment to Jihad." Dalam AARHUS Lecture Series 2010, 2010. 
Graff, Ronald Albert, dan Lambert T. Dolphin. Connecting the Dots: A Handbook of Bible Prophecy. Longwood: Xulon Press, 2010.

Hassan, Riffat “Messianism and Islam." Journal of Ecumenical Studies 22, no. 2 (1985): 261-91. http://soerenkern.com/pdfs/islam/MessianismAndIslamHassan. pdf.

Humphreys, R. Stephen. Islamic History: A Framework for Inquiry. Revised. Princeton: Princeton University Press, 1991.

Ibn Ḥanbal, Abū 'Abdullāh Aḥmad ibn Muhammad al-Shaibāni. al-Musnad alImām Ahmad ibn Hanbal. Ed. Shu'aib Al-Arna'ūte. Beirut: Mu'assasah alRisālah, 2001.

Ibn Khaldūn, Abū Zaid 'Abd al-Raḥmān ibn Muhammad. "Bāb fi Amri al-Fāṭimī wa Mā Yazhhabu ilaihi al-Nās fi Sha'nihi." Dalam al-Muqaddimah li Ibn Khaldūn, Ed. 'Abdullāh Muhammad Darwis, Vol. 1. Damsyiq: Dār Yu'rab, 2004.

———. The Muqaddimah: An Introduction to History. Ed. N. J. Dawood. Terj. Franz Rosenthal. Princeton: Princeton University Press, 2015.

Ibn Mājah, Abū 'Abdullāh Muhammad ibn Yazīd al-Qazwīnī. "Bāb Khurūj alMahdi." Dalam Sunan Ibn Mājah, Ed. Muhammad Fuad 'Abd al-Bāqi. Cairo: Dār Ihyā’ al-Kutub al-Arabiyyah, n.d.

Ibn Abī Shaibah, Abū Bakar al-'Abbasiy. Mușannaf Ibn Abi Shaibah. Ed. Kamāl Yūsūf al-Hūt. Riyāz: Maktabah al-Rashd, 1409.

al-Khuzai, Abū 'Abdullāh Nu'aim ibn Hammad ibn Mu'awiyah ibn al-Harith. Kitāb al-Fitan. Ed. Samīr Amīn al-Zuhairi. Vol. 2. Cairo: Maktabah al-Tawhīd, 1412.

Kuntowijoyo. "Sejarah Pemikiran." Dalam Metodologi Sejarah. Yogyakarta: Tiara Wacana, 2003.

Livne-Kafri, Ofer. "Some Notes on the Muslim Apocalyptic Tradition." Quaderni di Studi Arabi 17 (1999): 71-94. https://doi.org/10.2307/25802868.

- _ - "Some Observations on the Migration of Apocalyptic Features in Muslim Tradition." Acta Orientalia Academiae Scientiarum Hungaricae 60, no. 4 (2007): 467-77. https://doi.org/10.2307/23658770.

Makin, Al. Nabi-Nabi Nusantara: Kisah Lia Eden dan Lainnya. Yogyakarta: SUKAPress, 2017. 
—_- Representing the Enemy: Musaylima in Muslim Literature. Frankfurt: Peter Lang, 2010.

Mālik, Muhammad Mahjūb. al-Muqāwamah al-Dākhiliyyah li Harakati alMahdiyyah. Beirut: Dār al-Jail, 1987.

Muqtada, Muhammad Rikza. "Radicalism in Islam: The Politicization of the Mahdawiyah Hadith among the Mahdi Movement." Kalam 13, no. 1 (2019): 85-112. https://doi.org/10.24042/klm.v13i1.4069.

Murawiec, Laurent. The Mind of Jihad. 1 ed. Cambridge; New York: Cambridge University Press, 2008.

al-Nisāburī, Abū Abdillāh Muḥammad ibn 'Abdullāh al-Ḥākim. al-Mustadrak 'alā al-Ṣahīhaini. Ed. Mușțafă 'Abd al-Qādir 'Ața. Beirut: Dār al-Kutub al'Ilmiyyah, 1990.

al-Nisāburī, Muslim ibn al-Ḥajāj Abū al-Ḥasan al-Qushairī. "Bāb al-Imārah.” Dalam al-Musnad al-Șahịh al-Mukhtașar Șahịh Imām Muslim, Vol. 3. Beirut: Dār Ihyā' al-Turath al-'Arabī, n.d.

Nahdi, Saleh Asyabibi. Imam Mahdi Atau Ratu Adil? Jakarta: Arista Brahmatyasa, 1992.

Powers, David S. Studies in Qur'an and Hadith: The Formation of the Islamic Law of Inheritance. London: University of California Press, 1986.

al-Qummi, Abū Ja'far Muḥammad ibn 'Alī ibn al-Ḥusain. "Naș Allāh swt. 'alā alQā’im as." Dalam Kamāl al-Dīn wa Itmām al-Ni'mah, Ed. Husain al-A'lāmi, Vol. 23. Beirut: Muassasah al-A'lāmī li al-Mațbū'āt, 1991.

al-Rāzī, Abū Ja'far Muhammad ibn Ya'qūb ibn Isḥāq al-Kulaini. al-Kāfi li al-Kulaini. Ed. Alī Akbar al-Ghifarī. Vol. 1. Teheran: Dār al-Kutub al-Islāmī, 1363.

Rahman, Fazlur. Islam. Chicago \& London: University of Chicago Press, 1977.

Santosa, Nyong Eka Teguh Iman. Sejarah Intelektual: Sebuah Pengantar. Sidoarjo: UruAnna, 2014.

Saritoprak, Zeki. "The Mahdī Tradition in Islam: A Social-Cognitive Approach." Islamic Studies 41, no. 4 (2002): 651-74. https://doi.org/10.2307/ 20837234.

Sulaiman, Rusydi. Pengantar Metodologi Studi Sejarah Peradaban Islam. Jakarta: Raja Grafindo Persada, 2014. 
Tawakkal, 'Abd al-Fatah. "Ka'b al-Aḥbār and the Isräiliyyāt in the Tafsīr Literature." Montreal: McGill University, 2007.

Thrupp, Sylvia L. "Impian-impian Millenial di dalam Aksi: Laporan Mengenai Diskusi Konperensi." Dalam Gebrakan Kaum Mahdi: Studi tentang Gerakan-Gerakan Keagamaan Revolusioner, Ed. Sylvia L. Thrupp dan Tohiruddin Lubis, terj. Anas Muhyiddin. Bandung: Pustaka, 1984.

Wattimena, Reza. Melampaui Negara Hukum Klasik (Locke - Rousseau Habermas). Yogyakarta: Kanisius, 2007.

Wilar, Abraham Silo. "Muhammad as Seal of the Prophets: The Question of Ideology in Majority Muslim, Ahmadiya Muslim, and Western Readings of Seal." Penamas 27, no. 2 (2014): 137-148. http://blajakarta.kemenag. go.id/journal/index.php/penamas/article/view/75.

Yaocof, Yehoiakin Ben. Concepts of Messiah: A Study of the Messianic Concepts of Islam, Judaism, Messianic Judaism, Christianity. Bloomongton, Indianapolis: WestBow Press, 2012.

Yazigi, Maya. "William F. Tucker, Mahdis and Millenarians: Shi'ite Extremists in Early Muslim Iraq (Cambridge: Cambridge University Press, 2008). Pp. 204. \$96.00 cloth, \$30.00 paper, \$68.00 e-book." International Journal of Middle East Studies 43, no. 3 (2011): 573-75. https://doi.org/10.1017/ S0020743811000808.

Yousofi, Morteza. "Reading Robinson Crusoe from the lens of Islamic Utopianism." International Journal of Applied Linguistics \& English Literature 3, no. 2 (2014): 187-93. https://doi.org/10.7575/aiac.ijalel.v.3n.2p.187.

al-Ẓahabī, Shamsuddīn Muḥammad ibn Aḥmad ibn Uthmān. Talkhīs Kitāb al-'Ilal al-Mutanāhiyah li Ibn al-Jauzī. Ed. Abū Tamīm Yasīr ibn Ibrāhīm. Riyāẓ: Shirkah al-Riyāz, 1998. 
